\section{Evaluation of Plantable Containers for Groundcover Plant Production and Their Establishment in a Landscape}

\author{
Susmitha S. Nambuthiri and Dewayne L. Ingram ${ }^{1}$
}

ADDITIONAL INDEX WORDS. herbaceous perennials, sustainable systems

SuMmary. The demand for groundcover plants for landscape use is increasing. Plantable containers are becoming available in sizes appropriate for groundcover plants. Landscapers are seeking ways to decrease the time required to prepare and plant groundcover beds. Studies were conducted in 2011 and 2012 to evaluate plantable containers for a variety of groundcover plants. The study has shown that 'Bronze Beauty' ajuga (Ajuga reptans), 'Herman's Pride' lamiastrum (Lamiastrum galeobdolon), 'Beacon Silver' lamium (Lamium maculatum), 'Immergrunchen sedum (Sedum bybridum), 'Red Carpet Stonecrop' sedum (Sedum spurium), and 'Vera Jameson' sedum (Sedum telephium) were grown to a marketable size from 1.5inch plugs in 8 weeks in Lexington, KY, when transplanted in May through August. 'Big Blue' liriope (Liviope muscari) from bare root bibs required 12 weeks. Plant growth in a $90-\mathrm{mm}$ paper container and $80-\mathrm{mm}$ bioplastic container was similar to that of plants grown in standard 3-inch rigid plastic containers and required $20 \%$ less time to transplant into the landscape and grew rapidly after transplanting in the field. Peat containers in this production system yielded smaller plants and slower ground coverage after transplanting in the field than plants grown in the other containers.

$\mathrm{T}$ The demand for groundcover plants in residential and commercial landscapes is increasing due to several reasons, such as aesthetic appeal of masses of these low-growing plants in small- to medium-sized areas of the landscape, enhanced environmental impact by reducing storm water runoff velocity, controlling weeds in landscapes, and low maintenance requirements (Klett and Wilson, 2009). Niemiera (2012) provided a list of plants that can be used as groundcovers that perform well in various soil and light conditions. The increasing variety of plant materials suitable for use en masse as groundcovers is providing more opportunities for consumers and landscape designers. Groundcover plants are available to landscapers as small plants in celled flats or bare root, or as more mature plants in \#l (1-gal) containers. The cost of large numbers of plants required to cover an area is often a limiting factor considering most landscape installation budgets. Conversations (personal contact) with

Department of Horticulture, University of Kentucky, N-318 Ag Science North, Lexington, KY 405460091

This project was funded in part by a U.S. Department of Agriculture. Specialty Crop Block Grant is funded through the Kentucky Department of Agriculture.

${ }^{1}$ Corresponding author. E-mail: dingram@uky.edu. landscapers reveal their need for locally available perennial groundcover plants of a size that reduces maintenance requirements and gives a relatively quick cover in the landscape. Landscapers are also seeking increased labor efficiency in establishing groundcover beds. The landscape industry is a visible segment of the green industry and having hundreds of plastic containers scattered across a client's landscape during installation, which must be collected and disposed of or recycled, detract from its image. Recycling of plastic containers is not readily available in some areas (Hurley, 2008). Also, many consumers view the production of groundcovers in individual plastic containers as an unsustainable practice (Hall et al., 2010). Plantable containers that could be used efficiently in a groundcover production and marketing system would allow landscapers to differentiate themselves in the market as offering more ecofriendly products and services. Crop turnover in 8 to 10 weeks may allow growers to keep the price point at a reasonable level for mass plantings.

An increasing number of biodegradable and plantable containers are becoming available in sizes appropriate for groundcover plant production. These containers are made from paper, straw, composted manure, wood fiber, peat, coir fiber, rice hulls, and bioplastics (Nambuthiri et al., 2013), and commonly range in size from 5 to $15 \mathrm{~cm}$ in diameter. Production container design must also address the ease of maintenance on job sites and/or in the retail environment. There are several products now on the market aimed at these criteria. Use of ecofriendly containers for producing groundcover plants could make businesses more "green" and enhance customer acceptance (Dennis et al., 2010; Hall et al., 2010).

Two experiments were conducted. The 2011 study evaluated plants with potential suitability for a rapid turnover system for groundcover production in flats and using plantable containers compared with standard plastic containers. The 2012 study built on information gleaned from the 2011 study and evaluated plant performance during production and in the landscape from the same production system but with multiple planting dates.

\section{Materials and methods}

Experiments were conducted in 2011 and 2012 at the University of Kentucky Horticulture Research Farm in Lexington, $\mathrm{KY}$ (lat. $38^{\circ} 3^{\prime} \mathrm{N}$, long. $84^{\circ} 30^{\prime} \mathrm{W}$, elevation $1250 \mathrm{ft}$ ). Hourly weather data were obtained from an on-farm weather station and monthly mean air temperature and cumulative precipitation were reported as July $\left(79.1^{\circ} \mathrm{F}, 3.5\right.$ inches), August

\begin{tabular}{llll}
\hline $\begin{array}{l}\text { Units } \\
\text { To convert U.S. to SI, } \\
\text { multiply by }\end{array}$ & U.S. unit & SI unit & $\begin{array}{l}\text { To convert SI to U.S., } \\
\text { multiply by }\end{array}$ \\
\hline 0.3048 & $\mathrm{ft}$ & $\mathrm{m}$ & 3.2808 \\
3.7854 & gal & $\mathrm{L}$ & 0.2642 \\
2.54 & inch $(\mathrm{es})$ & $\mathrm{cm}$ & 0.3937 \\
25.4 & inch $(\mathrm{es})$ & $\mathrm{mm}$ & 0.0394 \\
16.3871 & inch & $\mathrm{cm}^{3}$ & 0.0610 \\
28.3495 & $\mathrm{Oz}$ & $\mathrm{g}$ & 0.0353 \\
1 & $\mathrm{ppm}$ & $\mathrm{mg} \cdot \mathrm{L}^{-1}$ & 1 \\
$\left({ }^{\circ} \mathrm{F}-32\right) \div 1.8$ & ${ }^{\circ} \mathrm{F}$ & ${ }^{\circ} \mathrm{C}$ & $\left({ }^{\circ} \mathrm{C} \times 1.8\right)+32$ \\
& & &
\end{tabular}


(75 ${ }^{\circ} \mathrm{F}, 4$ inches), and September (65 ${ }^{\circ} \mathrm{F}, 6.5$ inches) of 2011 and March (46.4 ${ }^{\circ} \mathrm{F}, 0.5$ inches), April (56 ${ }^{\circ} \mathrm{F}, 2$ inches), May $\left(69^{\circ} \mathrm{F}, 4\right.$ inches), June $\left(73^{\circ} \mathrm{F}, 1\right.$ inch), July

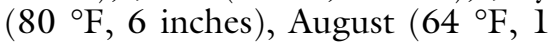
inch), and September ( $65^{\circ} \mathrm{F}, 6.5$ inches) of 2012 .

In 2011, 'Immergrunchen' sedum and 'Red Carpet Stonecrop' sedum plugs from 72 -count flats $(\approx 1.5$ inch-diameter cells) supplied by Midwest Groundcovers (St. Charles, IL) and bare root 'Big blue' liriope bibs obtained from Classic Groundcovers, Inc. (Athens, GA) were transplanted into one of three containers in midApril. Container types were the following: standard 3-inch-diameter, round plastic containers $\left(300 \mathrm{~cm}^{3}\right.$ volume $)$ in 12 -count flats, and two plantable and biodegradable containers: $90-\mathrm{mm}-$ diameter, bottomless, paper container $\left[570 \mathrm{~cm}^{3}\right.$ volume (Ellepot; Ellegaard, Storstrømsvej, Denmark)] in 10-count flats or 80-mm-diameter, bottomless, bioplastic container [330 $\mathrm{cm}^{3}$ volume (SoilWrap; Ball Horticultural Co., Chicago, IL)] in 12-count flats. In addition to the above three container types, only liriope were also grown in plantable containers made from rice hull [3.25-inch square, $473 \mathrm{~cm}^{3}$ volume (NetPot; Summit Plastics Co., Tallmadge, $\mathrm{OH})$ ]. The paper containers were made with paper with a 4- to 6-month decomposition timeline. The bioplastic container is composed of a biopolymer (Mirel; Metabolix, Cambridge, MA), based on polyhydroxyl alkanoate polymers and produced by fermenting renewable carbon-based feed stocks, principally corn (Knights, 2011). Each species was transplanted to three flats of each container tested. Jiffy Blend \#8 substrate (Jiffy Products of America, Lorain, $\mathrm{OH}$ ) was used in the bioplastic and plastic containers to emulate the paper container substrate.

Plants were fertigated once with $200 \mathrm{mg} \cdot \mathrm{L}^{-1}$ of nitrogen $(\mathrm{N})$ solution from 21N-2.2P-16.6K (Peters Excel; Everris NA, Dublin, $\mathrm{OH}$ ) topdressed with $3.5 \mathrm{~g}$ of $15 \mathrm{~N}-3.9 \mathrm{P}-9.9 \mathrm{~K}$ controlled-release fertilizer (Osmocote Plus, Everris NA) in early May, and moved to a $24 \times 50$-ft quonset-type, nonheated shade house (47\% shade) with a single layer clear plastic cover, side ventilation and no ends. The water status of each flat was visually assessed twice daily and hand-watered to container capacity with municipal water as needed. Plant size index (height plus the mean width in two directions) measurements of both sedum cultivars and the number of offshoots per liriope plant were collected before transplanting to the field. After 10 weeks (29 Aug. 2011) the sedum cultivars were transplanted into a field plot with a Maury silt loam series (mesic Typic Paleudalfs) soil that had been cleared of debris and tilled. Liriope reached a marketable size at 12 weeks after transplanting into the containers and were then transplanted to the field. Plants grown in paper, bioplastic, and rice hull containers were planted with the container, and plants grown in plastic containers were removed from containers and planted on $\mathrm{l}$ - $\mathrm{ft}$ centers in a triangular arrangement in three replicate blocks per species, one flat per block. Field plots were mulched to a 1-inch depth with pine bark and watered thoroughly by hand three times the first week and as needed (about twice per week) thereafter.

Digital images of ground coverage were taken of the sedum every 2 to 4 weeks to assess changes in plant growth and ground coverage until it became difficult to measure individual plant growth due to overlapping plant canopies. Images were collected using a digital camera with a fixed focal length positioned $6 \mathrm{ft}$ above the ground, and were analyzed using image analysis software (SigmaScan Pro 5.0; Systat Software, San Jose, CA). Images were calibrated each time using the known area of a frame $(100 \times$ $140 \mathrm{~cm}$ ) that was used to border each plot at the time of capturing images. Color images from the field were analyzed using either Image Color Threshold or Trace Mode function of the software to measure individual plant growth and ground coverage over time. Liriope plants were dug on 8 Nov. 2011, 9 weeks after transplanting to the field, and roots extending from the original container were harvested as a measure of root establishment. Roots were washed and oven-dried before being weighed.

In 2012, 'Bronze Beauty' ajuga, 'Herman's Pride' lamiastrum, 'Vera Jameson' sedum, and 'Beacon Silver' lamium plugs from 72-count flats $(\approx 1.5$-inch-diameter cells $)$ were supplied by Emerald Coast Growers (Pensacola, FL) with a similar physiological age for each transplanting date. Plants were transplanted into one of four test containers on 21 Mar., 20 Apr., 29 May, 26 July, 16 Aug., and 3 Oct. Containers tested were standard 3 -inch round plastic containers in 12-count flats and three plantable containers: $90-\mathrm{mm}$ paper containers in 10-count flats or $80-\mathrm{mm}$ bioplastic containers in 12-count flats as described above, or 3 -inch $\left(300 \mathrm{~cm}^{3}\right.$ volume) peat containers (Jiffy Products of America) in 12-count flats. Each species was transplanted to three flats of each container tested. The plant and container treatment combinations were factorially arranged in a randomized complete block design to evaluate potential production cycles. Plants were fertigated once with $200 \mathrm{mg} \cdot \mathrm{L}^{-1}$ $\mathrm{N}$ solution from $21 \mathrm{~N}-2.2 \mathrm{P}-16.6 \mathrm{~K}$ (Peters Excel), top-dressed 2 weeks later with $3.5 \mathrm{~g}$ of controlled-release 15N-3.9P-9.9K (Osmocote Plus), and grown in the quonset-style shade house described above except sidewalls and ends were enclosed for the months of March through April and September through December. Plants were hand-watered as described above. Plant size index of each species was recorded at 6 weeks after transplanting into test containers for each transplanting date.

On 5 July 2012, all the ajuga and lamiastrum plants that had been transplanted to the containers on $4 \mathrm{Apr}$. 2012 were transplanted into the field in three replicated blocks as in 2011 to determine any impact of container treatment on landscape establishment. These two plants represented the more aggressive and the less aggressive species studied. Early summer transplanting is common in Kentucky landscapes. Time required to transplant each flat was recorded. The plots were mulched and watered by hand as described above. In addition to periodic image analysis as described above to document ground coverage, three plants were dug from each block on 7 Nov. 2012, and the aboveground shoots and roots extending from the original container were harvested to determine if root growth into the surrounding soil was impacted by container. The roots were washed and oven-dried before being weighed. On 21 May 2013, three plants were dug from each replicate block to observe the extent of plantable container degradation. Data were subjected to analysis of variance followed by mean 
separation by Tukey's test at $P \leq 0.05$ (SAS version 9.1; SAS Institute, Cary, NC).

\section{Results and discussion}

Production, 2011. The two sedum cultivars had completely filled the flats and were estimated to be marketable 8 weeks (first week of July) after transplanting into the test containers. The mean size index of 'Immergrunchen' sedum and 'Red Carpet Stonecrop' sedum were (mean \pm SD) $22.9 \pm 2.4$ and $19.5 \pm 4.9 \mathrm{~cm}$, respectively, at transplanting into the field; the growth of the two cultivars was unaffected by container. Liriope were judged to have not filled the container to a point acceptable by the market until the end of August $(\approx 3$ months), though container type had no impact on the number of liriope off-shoots. By mid-June ( 8 weeks after transplanting), mean number of offshoots per plant was $2.0 \pm 1.3$, which increased to $4.6 \pm 1.2$ by mid-August.

LANDSCAPE ESTABLISHMENT, 2011. Using the image analyses of the sedum field plots, 'Red Carpet Stonecrop' sedum and the 'Immergrunchen' sedum had covered $27 \% \pm$ $2.5 \%$ and $38 \% \pm 3.3 \%$ of plot area in 2 weeks, $35 \% \pm 5.5 \%$ and $43 \% \pm 2.0 \%$ in 4 weeks, and $56 \% \pm 5.3 \%$ and $70 \% \pm$ $8.9 \%$ in 9 weeks, respectively. Container type did not influence the rate of coverage. By 24 Oct., 14 weeks after transplanting to the field, plants of both cultivars were intertwined and approaching complete coverage of the planted area with 'Red Carpet Stonecrop' sedum covering $82 \% \pm$ $5.7 \%$ and 'Immergrunchen' sedum covering $92 \% \pm 4.1 \%$ of the plot area. After 2 and 8 weeks, liriope had covered $26 \% \pm 2.3 \%$ and $43 \% \pm 3.7 \%$ of the ground area, respectively; the area covered was not impacted by production container.

Nine weeks after transplanting to the field, the mean dry weight of liriope roots extending from the original container substrate was $7 \pm 3.1 \mathrm{~g}$, and the mean number of off-shoots arising from below the soil surface was five to six per plant. There was no effect of the production containers on parameters measured at harvest from the field plot. Much of the rice hull container was intact and roots were growing through the slits in the container.

Production, 2012. For all transplanting dates and species tested, there was no difference in size due to container type. Ajuga transplanted in April or July were $18 \%$ smaller on average after 6 weeks than those transplanted in March or May (Table 1). Size index of lamiastrum transplanted in March, April, and July was almost $40 \%$ greater after 6 weeks compared with a May transplanting. Lamium and sedum size index after 6 weeks were unaffected by transplanting date. By 8 weeks, all species had filled the flat and were deemed to be marketable. Analysis of weather parameters did not reveal any apparent reason for less growth in the May transplanting.

LANDSCAPE ESTABLISHMENT, 2012. Transplanting of plants from plantable containers to the field plot took an average of 2 min 45 s per flat, whereas plants growing in the plastic containers took $20 \%$ more time (3 min $20 \mathrm{~s}$ ) for transplanting irrespective of plant species. Longer transplanting times for plastic containers were due to having to remove the container and collecting the empty containers after transplanting. Any additional time required for handling

Table 1. Impact of transplanting date on size index (height plus mean width in two directions) of ajuga 'Bronze Beauty', lamiastrum 'Herman's Pride', lamium 'Beacon Silver', and sedum 'Vera Jameson' grown in standard plastic or plantable containers for 6 weeks in a covered shade house in 2012.

\begin{tabular}{|c|c|c|c|c|}
\hline \multirow[b]{3}{*}{ Species } & \multicolumn{4}{|c|}{ Transplanting date } \\
\hline & March & April & May & July \\
\hline & \multicolumn{4}{|c|}{ Size index $(\mathrm{cm})^{\mathrm{z}}$} \\
\hline Ajuga & $20.8 \mathrm{a}^{\mathrm{y}}$ & $16.2 \mathrm{~b}$ & $19.4 \mathrm{a}$ & $16.5 \mathrm{~b}$ \\
\hline Lamiastrum & $19.5 \mathrm{a}$ & $20.6 \mathrm{a}$ & $14.7 \mathrm{~b}$ & $21.2 \mathrm{a}$ \\
\hline Lamium & $14.1 \mathrm{a}$ & $15.2 \mathrm{a}$ & $15.4 \mathrm{a}$ & $15.8 \mathrm{a}$ \\
\hline Sedum & $20.1 \mathrm{a}$ & $21.6 \mathrm{a}$ & $22.2 \mathrm{a}$ & $22.5 \mathrm{a}$ \\
\hline
\end{tabular}

${ }^{\mathrm{z}}$ Size index $(\mathrm{cm})=($ height + mean width in two directions $) ; 1 \mathrm{~cm}=0.3937 \mathrm{inch}$

${ }^{y}$ Mean values with the same letter in a row do not significantly differ (Tukey's method, $P<0.05$ ).

the containers off-site or disposing of them was not considered.

Using the ground coverage image analysis of field plots, ajuga plants grown in the standard plastic, paper, and bioplastic containers produced $26 \%$ to $35 \%$ more ground coverage after 15 weeks than the plants grown in peat containers (Table 2). By the end of 15 weeks, lamiastrum plants produced in bioplastic containers, standard, and paper containers had covered 2.6, 2.4, and 1.9 times more soil surface than those grown in peat containers, respectively. Generally, the lamiastrum plants established poorly, especially if grown in peat containers. This could have been the result of above average air temperature and dry conditions in August (University of Kentucky, 2012). Twice per week irrigation may have been inadequate for plants grown in peat containers compared with plants grown in the other containers as peat containers wick water from soil, reducing plantavailable water (Evans et al., 2010). Four months after transplanting to the field (November), ajuga plants had produced a mean of 55 off-shoots arising from below the soil surface, but this was not influenced by container type.

The mean dry weight of ajuga roots extending from the original container and aboveground shoots, measured at harvest from the field plot, was largest when grown in paper containers (Table 3 ). It is possible that the greater shoot and root dry weights could have been influenced by the larger volume of the paper container. Ajuga grown in bioplastic containers, standard plastic and peat containers produced similar root growth outside the original container, but plants produced in peat containers had less shoot dry weight at harvest from the field than plants grown in standard, bioplastic, or paper containers.

Lamiastrum plants grown in paper containers had the highest mean shoot dry weight at harvest from the field after 4 months compared with other containers (Table 3). This could have been influenced by the larger container volume of the paper containers. Plants grown in bioplastic and standard containers produced similar shoot dry weight and plants grown in peat containers produced the lowest shoot dry weight. Dry 
Table 2. Percentage groundcover over time after field transplanting of ajuga 'Bronze Beauty' and lamiastrum 'Herman's Pride' plants grown in standard plastic or plantable containers in 2012.

\begin{tabular}{|c|c|c|c|c|c|c|c|c|}
\hline \multirow[b]{2}{*}{ Container type } & \multicolumn{4}{|c|}{ Time after transplanting ajuga (weeks) } & \multicolumn{4}{|c|}{ Time after transplanting lamiastrum (weeks) } \\
\hline & 2 & 4 & 9 & 15 & 2 & 4 & 9 & 15 \\
\hline Standard ${ }^{\mathrm{z}}$ & $24.9 \mathrm{a}^{\mathrm{y}}$ & $51.4 \mathrm{a}$ & $64.3 \mathrm{a}$ & $80.2 \mathrm{a}$ & $10.2 \mathrm{a}$ & $12.9 \mathrm{a}$ & $15.4 \mathrm{a}$ & $21.4 \mathrm{a}$ \\
\hline Paperw & $25.3 \mathrm{a}$ & $46.8 \mathrm{ab}$ & $64.0 \mathrm{a}$ & $77.8 \mathrm{a}$ & $10.2 \mathrm{a}$ & $11.5 \mathrm{a}$ & $11.2 \mathrm{a}$ & $16.7 \mathrm{a}$ \\
\hline Peat $^{\mathrm{v}}$ & $24.9 \mathrm{a}$ & $34.4 \mathrm{c}$ & $43.6 \mathrm{~b}$ & $59.4 \mathrm{~b}$ & $9.9 \mathrm{a}$ & $5.3 \mathrm{c}$ & $6.0 \mathrm{~b}$ & $8.8 \mathrm{~b}$ \\
\hline
\end{tabular}

${ }^{\mathrm{z}} 3$-inch-diameter $\left(300 \mathrm{~cm}^{3}\right.$ volume $)$, round plastic containers; 1 inch $=25.4 \mathrm{~mm}, 1 \mathrm{~cm}^{3}=0.0610 \mathrm{inch}^{3}$.

${ }^{y}$ Mean values within species with the same letter in a column do not significantly differ (Tukey's method, $P<0.05$ ).

${ }^{x}$ SoilWrap (Ball Horticultural Co., Chicago, IL), 80 - $\mathrm{mm}$-diameter $\left(330 \mathrm{~cm}^{3}\right.$ volume) bioplastic container; $1 \mathrm{~mm}=0.0394 \mathrm{inch}$

wEllepots (Ellegaard, Storstrømsvej, Denmark), 90 -mm-diameter $\left(572 \mathrm{~cm}^{3}\right.$ volume) paper containers.

'3-inch-diameter $\left(300 \mathrm{~cm}^{3}\right.$ volume $)$ peat containers.

Table 3. Mean dry weight of shoot and root extending beyond the original container of ajuga 'Bronze Beauty' and lamiastrum 'Herman's Pride' grown in four container types and transplanted in the field for 4 mo. (July to November) in 2012.

\begin{tabular}{|c|c|c|c|c|}
\hline \multirow[b]{2}{*}{ Container type } & \multicolumn{2}{|c|}{ Ajuga } & \multicolumn{2}{|c|}{ Lamiastrum } \\
\hline & Shoot $(g)^{z}$ & $\operatorname{Root}(\mathrm{g})$ & Shoot $(g)$ & $\operatorname{Root}(\mathrm{g})$ \\
\hline Standard ${ }^{y}$ & $151.4 \mathrm{~b}^{\mathrm{x}}$ & $16.2 \mathrm{~b}$ & $16.8 \mathrm{~b}$ & $17.0 \mathrm{a}$ \\
\hline Paperw & $225.2 \mathrm{a}$ & $23.4 \mathrm{a}$ & $37.1 \mathrm{a}$ & $9.0 \mathrm{~b}$ \\
\hline Bioplastic $^{\mathrm{v}}$ & $135.3 \mathrm{~b}$ & $16.3 \mathrm{~b}$ & $20.2 \mathrm{~b}$ & $11.8 \mathrm{~b}$ \\
\hline Peat $^{\mathrm{u}}$ & $115.9 \mathrm{c}$ & $13.9 \mathrm{~b}$ & $7.8 \mathrm{c}$ & $12.3 \mathrm{~b}$ \\
\hline
\end{tabular}

${ }^{\mathrm{z}} \mathrm{lg}=0.0353 \mathrm{oz}$.

y 3 -inch-diameter $\left(300 \mathrm{~cm}^{3}\right.$ volume $)$, round plastic containers in 12 -count flats; 1 inch $=25.4 \mathrm{~mm} ; 1 \mathrm{~cm}^{3}=0.0610$ inch $^{3}$.

${ }^{x}$ Mean values within species with the same letter in a column do not significantly differ (Tukey's method, $P<0.05$ ). wSoilWrap (Ball Horticultural Co., Chicago, IL), $80-\mathrm{mm}$-diameter $\left(330 \mathrm{~cm}^{3}\right.$ volume) bioplastic container in 12 count flats; $1 \mathrm{~mm}=0.0394$ inch

"Ellepots (Ellegaard, Storstrømsvej, Denmark), 90 -mm-diameter $\left(572 \mathrm{~cm}^{3}\right.$ volume $)$ paper containers in 10 -count flats.

u 3 -inch-diameter $\left(300 \mathrm{~cm}^{3}\right.$ volume $)$ peat containers in 12 -count flats.

weight of lamiastrum roots extending from the original container substrate was quite variable but was higher from plants grown in standard plastic containers than the three plantable containers.

The paper and bioplastic containers began to break down after 10 weeks of production and were almost completely degraded after 4 months in the field plot. There were a few pieces of the bioplastic containers remaining but those were primarily near the soil surface and did not appear to interfere with plant establishment. A significant portion of the peat containers remained intact 11 months after transplanting with roots extending primarily from below the containers with few roots having penetrated the peat containers. Koeser (2013) observed that peat containers limited crop growth in transplanted impatiens (Impatiens Xbybrida 'Sunpatiens Compact'). Appleton (1993) reported that slow container degradation offered little benefit to landscape establishment and could cause root circling, leading to restricted water and nutrient movement and ability to adequately anchor. A high carbon-tonitrogen ratio (138:1) of peat containers (S. Nambuthiri, unpublished data) may have limited their degradation in the field.

Several test plants grown in plantable containers such as the paper and bioplastic containers performed at least as well as plants grown in standard plastic containers in this study. The water wicking nature of peat containers along with their slow degradation in the landscape (Evans et al., 2010; Kuehny et al., 2011) could have negatively affected plant performance especially in the hot and dry Summer 2012, similar to that reported from a study growing vinca (Catheranthus roseus) and impatiens (Impatiens walleriana) in peat containers (Evans and Karcher, 2004).

These experiments showed that selected groundcover plants could be produced in 8 weeks in Lexington, $\mathrm{KY}$, in 80 - $\mathrm{mm}$ containers when transplanted from March through August. Sedum (Monterusso et al., 2005) and ajuga were candidates for rapid turnover systems for groundcover plant production, but liriope would require more production time than other genera tested. Plants grown in plantable containers required $20 \%$ less time to transplant into a prepared landscape site and resulted in labor savings and less plastic for recycling or disposal. Additional research is required to determine the consumer demand for these products.

\section{Literature cited}

Appleton, B.L. 1993. Nursery production alternatives for reduction or elimination of circling tree roots. J. Arboricult. 19:383-388.

Dennis, J.H., R.G. Lopez, B.K. Behe, C.R. Hall, C. Yue, and B.L. Campbell. 2010. Sustainable production practices adopted by greenhouse and nursery plant growers. HortScience 45:1232-1237.

Evans, M.R. and D. Karcher. 2004. Properties of plastic, peat and processed poultry feather growing containers. HortScience 39:1008-1011.

Evans, M.R., M. Taylor, and J. Kuehny. 2010. Physical properties of biocontainers for greenhouse crops production. HortTechnology 20:549-555.

Hall, C.R., B.L. Campbell, B.K. Behe, C. Yue, R.G. Lopez, and J.H. Dennis. 2010. The appeal of biodegradable packaging to floral consumers. HortScience 45:583-591.

Hurley, S. 2008. Postconsumer agricultural plastic report. California Integrated Waste Management Board. May 2008 Report. 14 Oct. 2013. <http://www. wastexchange.org/upload_publications/ CIWMBAgPlasticsReport.pdf>.

Klett, J.E. and C.R. Wilson. 2009. Xeriscaping: Ground cover plants. Colorado State Univ. Ext. Fact Sheet No. 7.230.

Knights, M. 2011. Processing biopolymers for rigid sheet and thermoforming. Tips and techniques: PHA extrusion/thermoforming. 23 Nov. 2013. 


\section{Research Reports}

<http://www.ptonline.com/articles/ processing-biopolymers-for-rigid-sheethermoforming $>$.

Koeser, A.K. 2013. Performance and environmental impacts of biocontainers in horticultural production systems. Univ. of Illinois, Urbana-Champaign, PhD Diss., 23 Nov. 2013. <https://www.ideals.illinois. edu/bitstream/handle/2142/44332/ Andrew_Koeser.pdf?sequence $=1>$.
Kuehny, J.S., M. Taylor, and M.R. Evans 2011. Greenhouse and landscape performance of bedding plants in biocontainers. HortTechnology 21:155-161.

Monterusso, M.A., D.B. Rowe, and C.L. Rugh. 2005. Establishment and persistence of Sedum spp. and native taxa for green roof applications. HortScience 40:391-396.

Nambuthiri, S., R. Schnelle, A. Fulcher, R. Geneve, A. Koeser, S. Verlinden, and
R. Conneway. 2013. Alternative containers for a sustainable greenhouse and nursery production. Univ. Kentucky Ext. Fact Sheet HortFact-6000.

Niemiera, A.X. 2012. Selecting landscape plants: Groundcovers. Virginia Coop. Ext. Publ. 426-609.

University of Kentucky. 2012. Kentucky Mesonet daily weather database. 15 Aug. 2013. <http://weather.uky.edu/php/ kymesonet_daily_ro_form.php>. 